\title{
CHARACTERIZATION OF THE EFFECTS OF MACRONUTRIENT DEFICIENCIES IN MANGABEIRA SEEDLINGS ${ }^{1}$
}

\author{
LAYARA ALEXANDRE BESSA², FABIANO GUIMARÃES SILVA², \\ MARIALVA ALVARENGA MOREIRA ${ }^{4}$, JOÃO PAULO RIBEIRO TEODORO 5 , \\ FREDERICO ANTÔNIO LOUREIRO SOARES ${ }^{3}$
}

ABSTRACT - Knowledge of the mineral nutrition requirements of mangabeira (Hancornia speciosa Gomes) is relatively scarce and rudimentary because there is a lack of consistent data concerning its nutritional demands at different developmental stages. The aim of this research was to characterize the visual symptoms of macronutrient deficiencies and to evaluate the effects of these deficiencies on the growth, the production of dry matter, and the leaf content of mangabeira. To achieve this goal, a greenhouse experiment was conducted at the Goiano Federal Institute (Instituto Federal Goiano) in Rio Verde - GO, from January to June 2011 in which mangabeira plants were arranged in a random block design and grown in nutrient solutions. This experiment was replicated four times. The plants were treated with either a complete nutrient solution or a nutrient solution from which the individual macronutrient of interest (nitrogen $(\mathrm{N})$, phosphorous $(\mathrm{P})$, potassium $(\mathrm{K})$, magnesium $(\mathrm{Mg})$, calcium $(\mathrm{Ca})$, or sulfur $(\mathrm{S})$ had been omitted. The omission of a macronutrient from the nutrient solution resulted in morphological alterations that were characteristic symptoms of the particular nutritional deficiency and caused decreases in growth and dry matter mass production. The accumulation of macronutrients displayed the following order in mangabeira leaves: $\mathrm{N}>\mathrm{K}>\mathrm{Ca}>\mathrm{P}>\mathrm{S}>\mathrm{Mg}$. Index terms: Hancornia speciosa Gomes, mineral nutrition, hydroponics.

\section{CARACTERIZAÇÃO DOS EFEITOS DE DEFICIÊNCIAS DE MACRONUTRIENTES EM MUDAS DE MANGABEIRA}

RESUMO - Os conhecimentos de nutrição mineral da mangabeira (Hancornia speciosa Gomes) são relativamente escassos e incipientes, faltando dados consistentes sobre sua demanda nutricional desde a fase de viveiro até a fase de produção. Com o objetivo de caracterizar os sintomas visuais de carências de macronutrientes, avaliar os efeitos da deficiência no crescimento, produção de massa da matéria seca e conteúdo foliar de mangabeira, foi conduzido um experimento em casa de vegetação no IF Goiano em Rio Verde - GO, nos períodos de janeiro a junho de 2011, onde plantas de mangaba foram cultivadas em solução nutritiva, no delineamento de blocos casualizados, com quatro repetições. Os tratamentos foram constituídos de solução nutritiva completa e omissão individual de nitrogênio $(\mathrm{N})$, fósforo $(\mathrm{P})$, potássio $(\mathrm{K})$, magnésio $(\mathrm{Mg})$, cálcio $(\mathrm{Ca})$ e enxofre $(\mathrm{S})$. A omissão dos nutrientes na solução nutritiva resultou em alterações morfológicas, traduzidas como sintomas característicos de deficiência nutricional, diminuição no crescimento e produção de massa da matéria seca, e o acúmulo de nutrientes apresentou a seguinte ordem decrescente para os macronutrientes: $\mathrm{N}>\mathrm{K}>\mathrm{Ca}>\mathrm{P}>\mathrm{S}>\mathrm{Mg}$ em folhas de mangabeira.

Termos para indexação: Hancornia speciosa Gomes, nutrição, avaliação estado nutricional, hidroponia.

\footnotetext{
1(Trabalho 098-12). Recebido em: 27-12-2011. Aceito para publicação em: 16-10-2012.

${ }^{2}$ Bióloga, mestranda em Ciência Agrárias, Instituto Federal Goiano - Câmpus Rio verde, caixa postal 66, CEP: 75901-970 - Rio Verde - GO. E-mail: layara.ifmorrinhos@hotmail.com (autor para correspondência)

${ }^{3}$ Professor Titular do Instituto Federal Goiano - Câmpus Rio Verde - GO

${ }^{4}$ Bolsista PNPD CAPES, Instituto Federal Goiano - Câmpus Rio Verde - GO

${ }^{5}$ Aluno de Agronomia, Instituto Federal Goiano - Câmpus Rio Verde - GO
} 


\section{INTRODUCTION}

Mangabeira (Hancornia speciosa Gomes) belongs to the Apocynaceae family and is a native fruit plant of Brazil that grows spontaneously in the Central West, North, Northeast, and Southeast regions. Mangabeira's fruit is valued because of its excellent organoleptic characteristics and its high nutritional content; notably, it has higher protein content than most fruits (LEDERMAN et al. 2000).

Large-scale processing of mangabeira is not performed because the volume of fruit currently available could not meet market demands. Therefore, capturing new markets, mainly in the South and the Southeast, relies on the establishment of commercial orchards because current production depends on extractivism (LEDERMAN et al. 2000). Commercial exploitation is closely related to successful seedling production; therefore, it is necessary to obtain healthy seedlings that can be planted in orchards. The growth of healthy seedlings will ensure the health of the plant in the field (ROSA et al. 2005).

Several studies have shown that nutrients can interfere with the development of mangabeira seedlings if not given in appropriate amounts (VIÉGAS et al. 2008). Therefore, it is necessary to establish the correct dosage of each nutrient to maximize seedling development and make their production economically viable. Understanding the nutritional needs of the plant, beginning with the seedling phase, will allow the correct dosages of nutrients to be established for the optimal growth of mangabeira plants (AUGOSTINHO et al. 2008).

Therefore, the objectives of this study were the characterization of the visual symptoms of macronutrient deficiencies and the evaluation of the effects of the deficiency on the growth, production of dry matter mass, and leaf content of mangabeira.

\section{MATERIALS AND METHODS}

The experiment was conducted in a greenhouse at the Plant Tissue Culture Laboratory of the IF Goiano - Rio Verde Campus between January and June of 2011.

Mangabeira fruit was collected at the Gameleira farm in the city of Montes Claros in the state of Goiás at the geographic coordinates $16^{\circ} 06^{\prime}$ $20^{\prime \prime} \mathrm{S}-51^{\circ} 17^{\prime} 11^{\prime \prime} \mathrm{W}$ and an altitude of $592 \mathrm{~m}$. Fruit harvest occurred in October and November 2010 under extractive mode, and the fruits were collected at the following geographical coordinates: $16^{\circ} 08^{\prime} 010^{\prime \prime} \mathrm{S}-51^{\circ} 18^{\prime} 169$ " $\mathrm{W}$ and $16^{\circ} 08^{\prime} 070$ ' $\mathrm{S}$ $-51^{\circ} 18^{\prime} 179^{\prime \prime} \mathrm{W}$, which correspond to an area of strictly Cerrado vegetation (Brazilian savanna) that has a local climate classification of AW, according to Köppen and Geiger (1928), with two distinct seasons: dry winter and rainy summer. The seeds were manually extracted from the mangabeira fruit, placed in a sieve to facilitate the removal of the pulp, and washed with running water. The collected seeds were subsequently sown in polystyrene trays, with each containing 72 cells filled with a 1:1 mixture of vermiculite and carbonized rice hulls. Thirty days after sowing, seedlings with 3-4 complete leaves were transferred to 8-L containers containing $1 / 2$-strength Hoagland's solution (HOAGLAND; ARNON, 1950) for 30 days. The plants were grown in complete 1/2-strength Hoagland's solution from which an individual macronutrient (nitrogen $(\mathrm{N})$, phosphorous $(\mathrm{P})$, potassium $(\mathrm{K})$, calcium $(\mathrm{Ca})$, magnesium $(\mathrm{Mg})$, or sulfur $(\mathrm{S})$ ) had been omitted. The plants were arranged in 28 parcels; each experimental parcel consisted of an 8-L container of nutrient solution with two plants.

The mangabeira plants were grown under an average irradiance of $200 \mu \mathrm{mol} \mathrm{m} \mathrm{m} \mathrm{s}^{-1}$, and the nutrient solution was continuously aerated with compressed air. If necessary, the $\mathrm{pH}$ was adjusted to $5.5 \pm 0.5$ daily by the addition of either $\mathrm{HCl}$ or $\mathrm{NaOH}$, and the nutrient solution was exchanged when the initial value of electrical conductivity had declined by $30 \%$. Evaluations of the visual symptoms of the nutritional deficiencies, which were described and photographed, were performed daily.

Evaluations of plant growth began 30 days after transplanting (DAT) the seedlings to the nutrientdeficient solutions. The stem length and diameter, the number of leaves, and the length of the largest root were measured; this procedure was repeated every 15 days as the symptoms of the deficiencies intensified until the plants were harvested. The plants were taken to the laboratory, where the leaf, stalk, and root were separated. To measure the dry matter mass of these organs, they were weighed and placed in an incubator set at $65^{\circ} \mathrm{C}$ until a constant mass was achieved. After drying, the leaves were ground in a Wiley-type mill equipped with a 20-mesh sieve and were taken to the leaf analysis laboratory of the Federal University of Lavras (Universidade Federal de Lavras - UFLA) to determine the quantities of macronutrients $(\mathrm{N}, \mathrm{P}, \mathrm{K}$, $\mathrm{Ca}, \mathrm{Mg}$ and $\mathrm{S}$ ) according to the method of Malavolta et al. (1997).

The ratio of the mass of the aerial parts to the mass of the roots $(\mathrm{AP} / \mathrm{R})$ was calculated by dividing the sum of the masses of the stalk and leaf dry matter by the mass of the dry matter of the root. The relative growth $(\mathrm{RG})$ of the plant corresponded to the ratio of 
the total mass of the dry matter of the plants grown in a given nutrient-deficient solution to the total mass of the dry matter of plants grown in the complete nutrient solution multiplied by 100 .

The plants grown in the different nutrientdeficient solutions were arranged in a randomized block, and 4 replicates of each growth condition were performed. The data were subjected to an analysis of variance (ANOVA), and the means were compared by Tukey's test $(p<0.05)$, with the exception of stem length, stem diameter, root length and the number of leaves, the data for which are presented as descriptive images. It was necessary to transform the data obtained for the dry mass of the stalk, the dry mass of the root, the dry mass of the leaves, the total dry mass, the $R G$, and the $A P / R$ with an $x+1$ base to obtain a normal distribution and homogeneity of variances.

\section{RESULTS AND DISCUSSION}

\section{Visual symptoms of nutritional deficiency}

The visual symptoms of $\mathrm{N}$ deficiency began at 60 DAT. The greenest leaves gradually lost their dark green tone and became a pale green color, which was generally distributed throughout the leaf. Chlorosis occurred followed by necrosis and a reduction in the stalk's length (Figure 1). $\mathrm{N}$ is a mobile nutrient; therefore, when there is an insufficient supply, plant growth is slowed, and $\mathrm{N}$ is translocated from the older organs to the newer ones (MARSCHNER, 1995). The omission of $\mathrm{N}$ from the nutrient solution decreased the amount of chlorophyll in the plants (MALAVOLTA, 2006), resulting in the characteristic symptom of generalized chlorosis causing a general yellowing of the leaves. Similar results were observed in seedlings of soursop (Annona muricata L.) (BATISTA et al. 2003), teak (Tectona grandis L.f.) (BARROSO et al. 2005), and "Imperial" pineapple (Ananas comosus L.) (RAMOS et al. 2009) all of which had also evaluated nutrient deficiencies in greenhouses.

When plants were grown in the absence of $\mathrm{P}$, the symptoms were initially observed at 46 DAT. Chlorosis of the greenest leaves, which evolved into a purple color, a reduction in the stalk length, a lower number of leaves, and long, light-colored roots, were observed (Figure 1). Plants with a $\mathrm{P}$ deficiency experienced decreased growth because such processes as the syntheses of proteins and nucleic acids are affected (MALAVOLTA, 2006; ALVES et al. 2008). The symptoms of P deficiency in soursop also began in the lower leaves and later reached the medial and upper leaves (BATISTA et al. 2003).

The symptoms of $\mathrm{K}$ deficiency began at 43
DAT with the appearance of chlorosis and a small amount of red coloration at the leaf edges, which evolved into necrosis that reached the apices, the edges, and between the midribs of the leaves. As the symptoms of the deficiency progressed, large necrotic spots were displayed on the surfaces of the leaves and the roots became dark in color (Figure 1). In plants with a $\mathrm{K}$ deficiency, the soluble $\mathrm{N}$ compounds, including the amines and putrescine, often accumulate; the accumulation of the latter compound is probably responsible for the necrotic spots (MALAVOLTA, 2006). According to Malézieux and Bartholomew (2003), in the preliminary stages of $\mathrm{K}$ deficiency, the leaves of pineapple are dark green and narrow; however, if the deficiency is prolonged, the leaves become yellow.

The omission of $\mathrm{Ca}$ from the nutrient solution triggered the appearance of visual symptoms at 40 DAT. The edges of the youngest leaves wilted, and with the progression of the deficiency, necrosis, the death of shoots, and wilting of the entire leaf occurred (Figure 1). Plants require $\mathrm{Ca}$ in large quantities because it is one of the main components of the cell wall, where it is responsible for linking pectin molecules (WHITE; BROADLEY, 2009). A lack of $\mathrm{Ca}$ is characterized by a reduction in the growth of meristematic tissues, initially observed in the growth extremities and the youngest leaves (TAIZ; ZEIGER, 2004; ALVES et al. 2008). Batista et al. (2003) obtained similar results in Ca-deficient soursop, observing premature falling of the leaves and a halt in apical development. However, Ramos et al. (2009) did not observe the appearance of symptoms of Ca deficiency in "Imperial" pineapple.

The first visual symptom of Mg deficiency, interveinal chlorosis in the oldest leaves, was noticed at 35 DAT (Figure 1). As the symptoms worsened, early abscission of the leaves occurred. Additionally, a reduction in the lengths of the stalks and roots, which were still dark in color, was observed. Batista et al. (2003) had similar findings in Ca-deficient soursop. Because $\mathrm{Mg}$ is a component of the chlorophyll molecule, its deficiency reduces photosynthesis and plant growth (MALÉZIEUX; BARTHOLOMEW, 2003). In conditions of limited $\mathrm{Mg}, \mathrm{Mg}$ is easily distributed from the oldest organs of the plant to the newest ones because it is mobile. Therefore, the appearance of the visual symptoms of $\mathrm{Mg}$ deficiency appears in the oldest (greenest) leaves (MALAVOLTA, 2006).

S-deficient mangabeira plants began to show visual symptoms at 35 DAT. Chlorosis of the youngest leaves, which evolved into necrosis (Figure 1), a reduction in the length of the stalk, 
and underdeveloped roots with dark coloring, were observed. Batista et al. (2003) observed similar symptoms in soursop plants that were deficient in S. However, Ramos et al. (2009) did not observe any symptoms of S deficiency in "Imperial" pineapple. $\mathrm{S}$ is not notably mobile in the plant; therefore, the symptoms of its deficiency first appear in the youngest leaves (MALAVOLTA, 2006).

\section{Plant growth}

The lengths of the stalks were reduced in mangabeira plants that were grown in the nutrientdeficient solutions compared with the stalks of plants grown in the complete nutrient solution. Throughout the production cycle of mangabeira seedlings, a lack of $\mathrm{Mg}$ limited stalk growth the most; stalks of Mgdeficient mangabeira plants were $5.77 \mathrm{~cm}$ after 120 days, whereas plants grown in the complete nutrient solution had stalks that were $15.26 \mathrm{~cm}$ (Figure 2). The omission of $\mathrm{Mg}$ also limited the growth of Brazil plum (Spondias tuberosa) seedlings (GONÇALVES et al. 2006). However, Batista et al. (2003) observed that $\mathrm{N}$ was the macronutrient that most limited the height of soursop seedlings. Mg has a specific role in the activation of enzymes involved in the processes of respiration, photosynthesis, and DNA and RNA synthesis (TAIZ; ZEIGER, 2004).

Macronutrient deficiencies negatively affected plant growth, reducing the length of the stalk during the production cycle of mangabeira in the order $\mathrm{Mg}>\mathrm{Ca}>\mathrm{K}>\mathrm{P}>\mathrm{N}>\mathrm{S}$.

Cultivation in solutions from which macronutrients were omitted limited the growth of the stalk diameter of mangabeira plants compared with plants grown in the complete nutrient solution (Figure 3). Silva et al. (2005) found similar results in Brazil plum seedlings. $\mathrm{N}$ was the only nutrient that limited the growth of the stalk diameter of cricketvine (Arrabidaea chica (H. \& B.) Verlot); the stalk diameter was reduced $24 \%$ compared with cricketvine that had been grown in the complete nutrient solution (SILVA JÚNIOR et al. 2007). The development of the stalk diameter of soursop was most affected by deficiencies in $\mathrm{N}, \mathrm{Ca}$, and $\mathrm{P}$, the omission of which resulted in stalk diameters of 5.90 $\mathrm{mm}, 7.07 \mathrm{~mm}$, and $8.20 \mathrm{~mm}$, respectively, compared with soursop that had been grown in the complete nutrient solution, which had a stalk diameter of 20.85 mm (BATISTA et al. 2003).

The macronutrient deficiencies in mangabeira seedlings negatively affected the growth of the diameter of the stalk in the following order: $\mathrm{Ca}>\mathrm{P}>\mathrm{K}>\mathrm{Mg}>\mathrm{N}>\mathrm{S}$.

With the exception of the S-deficient nutrient solution, the omission of each of the other macronutrients limited the growth of the mangabeira root compared with the complete nutrient solution (Figure 6). When $\mathrm{S}$ was omitted from the solution, the roots were longer than the roots of plants receiving the complete nutrient solution; for plants grown without $\mathrm{S}$, the roots were $19.25 \mathrm{~cm}$ long, whereas the roots of plants grown in the complete nutrient solution were $19 \mathrm{~cm}$ long. For mangabeira seedlings, the omission of $\mathrm{Mg}$ most strongly limited the development of roots compared with seedlings receiving the complete nutrient solution. This phenomenon most likely occurred as a result of the composition of the salts used in the mineral solutions. In addition to being a cofactor for almost all of the enzymes involved in energy metabolism and an integral part of the chlorophyll molecule, $\mathrm{Mg}$ is required for the integrity of ribosomes and effectively contributes to the structural stability of nucleic acids and membranes (TAIZ; ZEIGER, 2004).

The deficiency of macronutrients in mangabeira seedlings negatively affected the growth of the roots in the following order: $\mathrm{Mg}>\mathrm{N}>\mathrm{Ca}>\mathrm{P}>\mathrm{K}>\mathrm{S}$.

With the exception of a deficiency in $\mathrm{S}$, deficiencies of all of the other macronutrients limited the number of mangabeira leaves compared with the plants grown in the complete nutrient solution (Figure 4).

The mangabeira plants lacking $\mathrm{Mg}$ had the fewest leaves. Plants growing without $\mathrm{Mg}$ had 3 leaves by 120 days, whereas plants growing in the complete nutrient solution had 14 leaves after the same number of days. The reduction in the number of leaves was $78.57 \%$ when $\mathrm{Mg}$ was omitted from the nutrient solution. The availability of $\mathrm{Mg}$ for the plants imposes limitations on photosynthesis it is essential for chloroplast function and is the main element in chlorophyll (TAIZ; ZEIGER, 2004; HERMANS; VERBRUGGEN, 2005). Viégas et al. (2008) found that a lack of $\mathrm{N}$ most limited the number of leaves for assai (Euterpe oleracea) seedlings, reducing the number by $50 \%$ compared with plants grown in a complete nutrient solution. The deficiency of macronutrients in mangabeira seedlings negatively affected the number of leaves in the following order: $\mathrm{Mg}>\mathrm{P}>\mathrm{K}>\mathrm{N}>\mathrm{Ca}>\mathrm{S}$.

\section{Production of dry matter}

The dry matter of the stalks and roots and the AP/R were not influenced by deficiencies in any of the macronutrients (Table 1).

The omission of $\mathrm{Mg}$ from the nutrient solution limited the dry matter masses of the leaves the most compared with the leaves of plants grown in the 
complete nutrient solution. There was a reduction by $78.43 \%$ in the dry mass of the leaves in $\mathrm{Mg}$ deficient mangabeira plants compared with the plants grown in the complete nutrient solution (Table 1). $\mathrm{Mg}$ participates in the organization of the thylakoid membranes and in grana stacking it also acts as a cofactor and activator of enzymes involved in the fixation of $\mathrm{CO}_{2}$ and is involved in the transference of energy through adenosine triphosphate and in pH control (HERMANS; VERBRUGGEN, 2005). $\mathrm{Mg}$ deficiency causes a reduction in photochemical reactions and in the fixation of $\mathrm{CO}_{2}$ (TAIZ; ZEIGER, 2004; HERMANS; VERBRUGGEN, 2005). Viégas et al. (2008) found that a deficiency of $\mathrm{N}$ was the most limiting for the production of the dry mass of leaves in assai palm seedlings.

The mass of the total dry matter was influenced by $\mathrm{Mg}$ deficiency (Table 1). A lack of this nutrient reduced the total dry mass of the mangabeira plants by $77.55 \%$ compared with plants grown in the complete nutrient solution. Similar results were obtained for teak seedlings (BARROSO et al. 2005) and horseradish tree seedlings (Moringa oleifera Lam.) (VIEIRA et al. 2008) that were subjected to an $\mathrm{Mg}$ deficiency. In soursop, a deficiency of $\mathrm{N}$ affected the production of the total dry matter the most (BATISTA et al. 2003).

The RG of mangabeira was influenced by the elimination of macronutrients from the nutrient solution (Table 1). The omission of $\mathrm{Mg}$ caused a reduction in $\mathrm{RG}$; the average value of $\mathrm{RG}$ was 25.13 , which represented a reduction of $74.87 \%$ compared with plants grown in the complete nutrient solution. Viégas et al. (2004) found that the RG of the camucamu plant (Myrciaria dubia (H. B. K.) McVaugh) was influenced by $\mathrm{N}$ deficiency; the dry matter was reduced by $84 \%$. Several authors have reported favorable results in the growth of fruit species, such as soursop or sweet passion fruit (Passiflora alata Dryand), in response to the addition of nutrients (BATISTA et al. 2003; FREITAS et al. 2006).

\section{Leaf macronutrient content}

The leaf macronutrient contents of mangabeira seedlings grown in both the complete nutrient solution and nutrient-deficient solutions are shown in Table 2. It was found that the contents of the macronutrients in the leaves of plants grown in the complete nutrient solution were the following: 10.0 mg plant ${ }^{-1}$ of $\mathrm{N}, 2.10 \mathrm{mg}_{\text {plant }}{ }^{-1}$ of $\mathrm{P}, 7.0 \mathrm{mg}^{\mathrm{m}}$ plant $^{-1}$ of K, $1.0 \mathrm{mg}$ plant $^{-1}$ of $\mathrm{Mg}, 4.0 \mathrm{mg}$ plant $^{-1}$ of $\mathrm{Ca}$, and $1.3 \mathrm{mg} \mathrm{plant}^{-1}$ of S. The leaf macronutrient contents of the seedlings grown in their respective nutrientdeficient solutions were $7.00 \mathrm{mg}$ plant $^{-1}$ of $\mathrm{N}, 0.10$ mg plant ${ }^{-1}$ of $\mathrm{P}, 4.0 \mathrm{mg} \mathrm{plant}^{-1}$ of K, $4.0 \mathrm{mg}$ plant $^{-1}$ of
$\mathrm{Mg}, 5.0 \mathrm{mg}$ plant $^{-1}$ of $\mathrm{Ca}$, and $0.6 \mathrm{mg}$ plant $^{-1}$ of $\mathrm{S}$. The leaf macronutrient content of mangabeira plants grown in the complete nutrient solution followed the order $\mathrm{N}>\mathrm{K}>\mathrm{Ca}>\mathrm{P}>\mathrm{S}>\mathrm{Mg}$, indicating that $\mathrm{N}$ is the macronutrient that accumulates the most in mangabeira leaves. Deficiency of any one nutrient may cause an imbalance in the other nutrients and may consequently lead to morphological changes, resulting in the characteristic symptoms of deficiency for each nutrient (MALAVOLTA, 2006).

The omission of $\mathrm{N}$ resulted in an elevated $\mathrm{N}$ content in the leaves; however, this amount did not differ from the values found in the leaves of the plants that received the complete nutrient solution. The lowest contents of $\mathrm{N}$ were found in the plants grown without $\mathrm{Mg}$, corresponding to a reduction of $82 \%$ compared with plants that were grown in the complete nutrient solution. A lack of $\mathrm{K}, \mathrm{Ca}$, or $\mathrm{S}$ resulted in a greater accumulation of $\mathrm{N}$ in the leaves. Malavolta (2006) reported that a deficiency of $\mathrm{K}$ leads to disturbances in the metabolism of $\mathrm{N}$, resulting in plants with greater quantities of free amino acids and their amides. As with $\mathrm{K}$ deficiency, a deficiency of S leads to a reduction in the synthesis of proteins and in the contents of chlorophyll and inorganic sulfate (MARRENCO; LOPES, 2005).

The plants that received the P-deficient nutrient solution displayed the lowest contents of $\mathrm{P}$ in the leaves compared with all of the other nutrients. The greatest accumulation of $\mathrm{P}$ occurred in the leaves of plants grown in the complete nutrient solution and in the S-deficient and Ca-deficient solutions.

The deficiencies of P affected the behavior of $\mathrm{Ca}$ because the addition of $\mathrm{P}$ to the medium favors the accumulation of Ca in the leaves (MALAVOLTA, 2006). Therefore, the lack of $P$ may have reduced the absorption of $\mathrm{Ca}$ by the plants. According to Malavolta (2006), the absorption of Ca may be decreased when high amounts of $\mathrm{K}, \mathrm{Mg}$, and $\mathrm{NH}_{4}^{+}$ are present in the medium. Therefore, the lack of $\mathrm{K}$ in the nutrient solution favors the accumulation of $\mathrm{Ca}$ by the plants.

The mangabeira plants grown without $\mathrm{Mg}$ displayed the lowest $\mathrm{K}$ contents in their leaves, exhibiting a reduction of $85.72 \%$ compared with plants grown in the complete nutrient solution.

Seedlings grown in the absence of $\mathrm{S}$ displayed a greater accumulation of $\mathrm{Ca}$ in the leaves. The increased contents of $\mathrm{Ca}$ and $\mathrm{Mg}$ observed in the mangabeira leaves of plants grown in the S-deficient nutrient solution may have been observed because the $\mathrm{N}$ in the S-deficient solution was in the form of $\mathrm{NO}_{3}$. Taiz and Zeiger (2004) reported that the rate of $\mathrm{Mg}$ absorption is negatively affected by $\mathrm{NH}_{4}{ }^{+}$. 


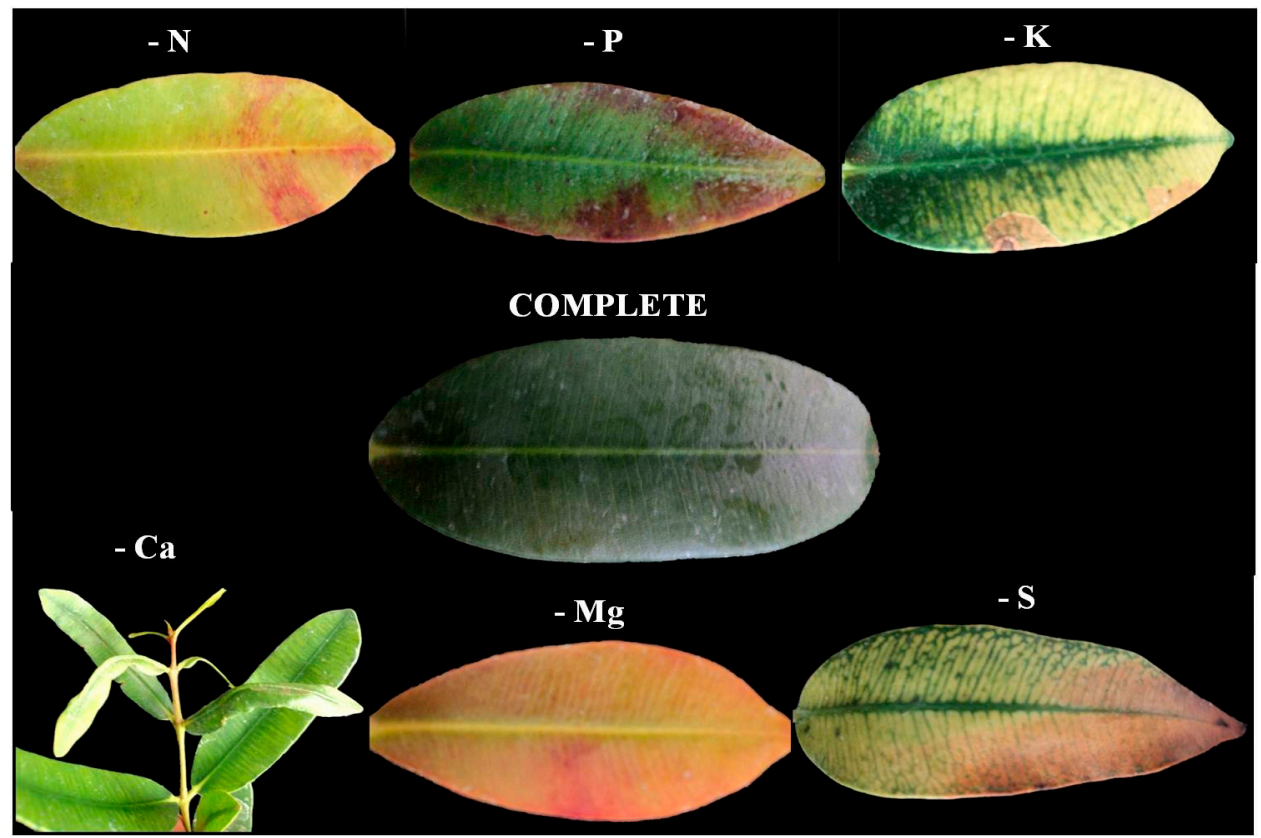

FIGURE 1 - Symptoms of nutritional deficiency in mangabeira seedlings (Hancornia speciosa Gomes) grown in the complete nutrient solution and in solutions deficient in $\mathrm{N}, \mathrm{P}, \mathrm{K}, \mathrm{Ca}, \mathrm{Mg}$, and $\mathrm{S}$.

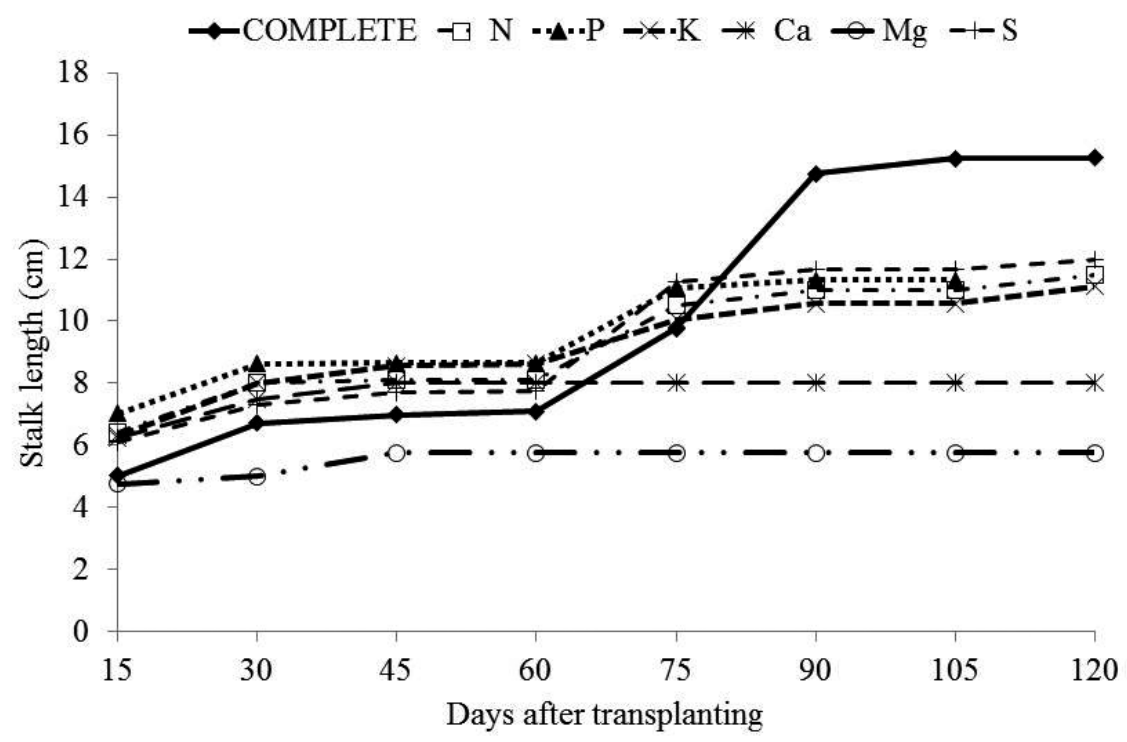

FIGURE 2- Stalk Length (cm) of mangabeira plants (Hancornia speciosa Gomes) between 15 and 120 DAT for each macronutrient deficiency. 


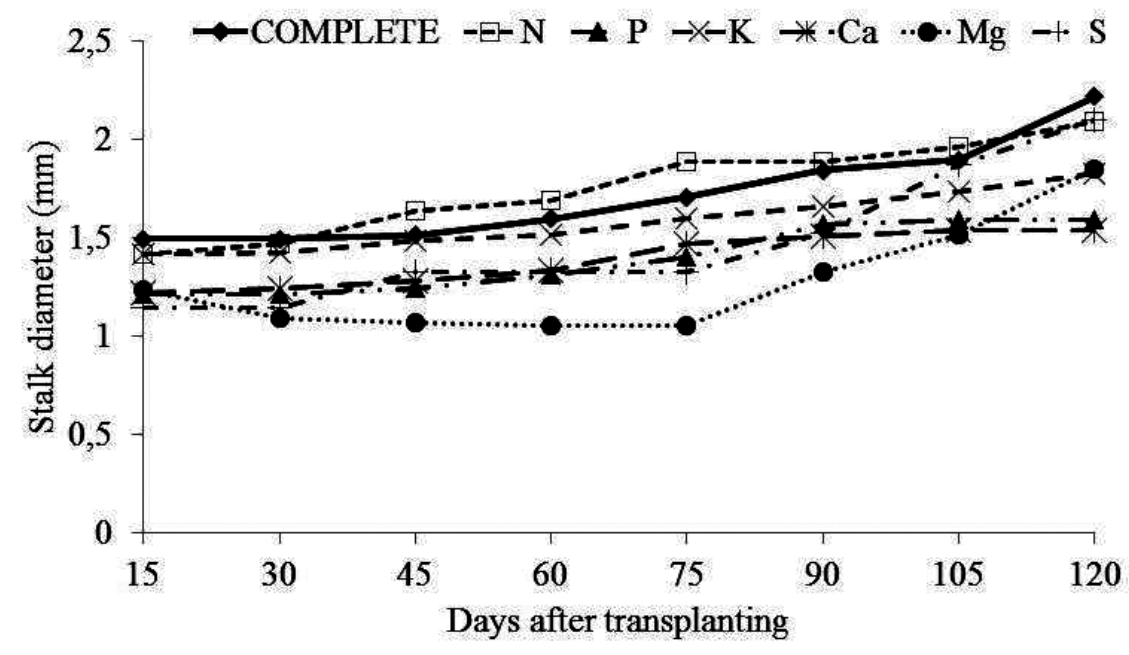

FIGURE 3- Stalk diameter (mm) of mangabeira plants (Hancornia speciosa Gomes) between 15 and 120 DAT for each macronutrient deficiency.

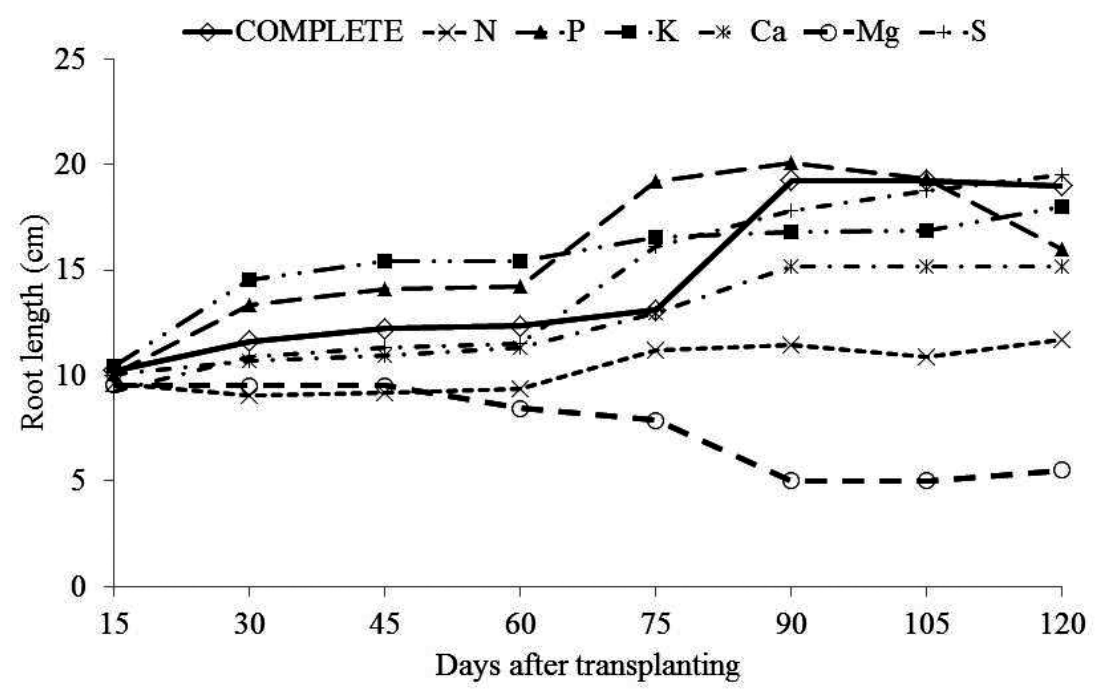

FIGURE 4- Root length (cm) of mangabeira plants (Hancornia speciosa Gomes) between 15 and 120 DAT for each macronutrient deficiency. 


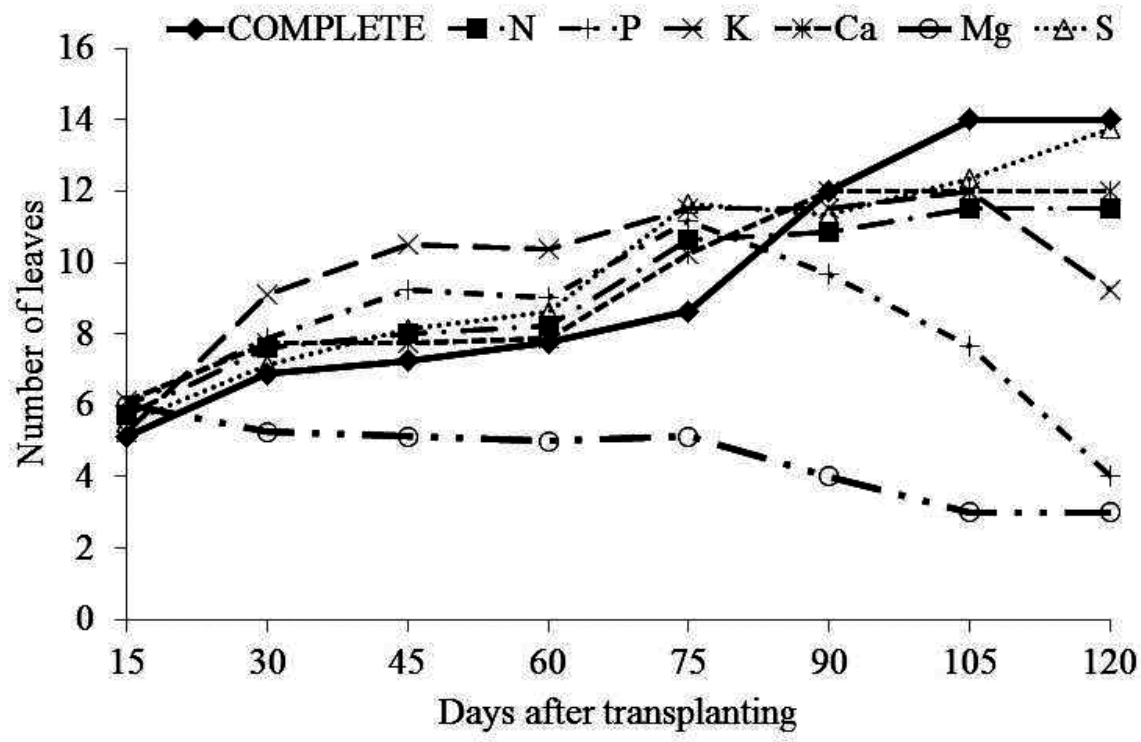

FIGURE 5 - Number of leaves of mangabeira plants (Hancornia speciosa Gomes) between 15 and 120 DAT for each macronutrient deficiency.

TABLE 1 - Dry matter of leaves (DML), stalk (DMS), and roots (DMR), total dry matter (TDM), RG, and AP/R in mangabeira seedlings (Hancornia speciosa Gomes) grown in complete nutrient solutions or in macronutrient-deficient solutions. Rio Verde. IF Goiano. 2011.

\begin{tabular}{lcccccc}
\hline \multicolumn{1}{c}{ TREATMENTS } & $\begin{array}{c}\text { DML } \\
(\mathbf{g})\end{array}$ & $\begin{array}{c}\text { DMS } \\
(\mathbf{g})\end{array}$ & $\begin{array}{c}\text { DMR } \\
(\mathbf{g})\end{array}$ & $\begin{array}{c}\text { TDM } \\
(\mathbf{g})\end{array}$ & $\begin{array}{c}\text { RG } \\
\mathbf{\%}\end{array}$ & AP/R \\
\hline $\mathbf{C O M P L E T E}$ & $0.51^{1} \mathrm{a}^{2}$ & $0.22 \mathrm{a}$ & $0.25 \mathrm{a}$ & $0.98 \mathrm{a}$ & $100 \mathrm{a}$ & $3.12 \mathrm{a}$ \\
$\mathbf{- ~ N}$ & $0.41 \mathrm{ab}$ & $0.14 \mathrm{a}$ & $0.36 \mathrm{a}$ & $0.92 \mathrm{ab}$ & $92.52 \mathrm{ab}$ & $1.74 \mathrm{a}$ \\
$\mathbf{- ~} \mathbf{P}$ & $0.18 \mathrm{ab}$ & $0.11 \mathrm{a}$ & $0.20 \mathrm{a}$ & $0.50 \mathrm{ab}$ & $51.40 \mathrm{ab}$ & $1.71 \mathrm{a}$ \\
$\mathbf{- ~ K}$ & $0.39 \mathrm{ab}$ & $0.18 \mathrm{a}$ & $0.34 \mathrm{a}$ & $0.92 \mathrm{ab}$ & $80,03 \mathrm{ab}$ & $1,83 \mathrm{a}$ \\
$\mathbf{- ~ M g}$ & $0.11 \mathrm{~b}$ & $0.03 \mathrm{a}$ & $0.07 \mathrm{a}$ & $0.22 \mathrm{~b}$ & $25.13 \mathrm{~b}$ & $2.35 \mathrm{a}$ \\
$\mathbf{- ~} \mathbf{C a}$ & $0.38 \mathrm{ab}$ & $0.14 \mathrm{a}$ & $0.26 \mathrm{a}$ & $0.80 \mathrm{ab}$ & $85.95 \mathrm{ab}$ & $2.19 \mathrm{a}$ \\
$\mathbf{- S}$ & $0.39 \mathrm{ab}$ & $0.10 \mathrm{a}$ & $0.26 \mathrm{a}$ & $0.75 \mathrm{ab}$ & $76.78 \mathrm{ab}$ & $2.47 \mathrm{a}$ \\
\hline $\mathbf{C V}(\%)^{3}$ & 5.84 & 4.39 & 5.28 & 8.59 & 21.25 & 16.48 \\
\hline
\end{tabular}

${ }^{1}$ Means shown with the original values. ${ }^{2}$ Means followed by the same letter in the column do not statistically differ according to Tukey's test $(\mathrm{p}<0.05) .{ }^{3}$ Coefficients of variation obtained after the data were transformed with an $\mathrm{x}+1$ base.

TABLE 2 - Leaf macronutrient content (mg plant ${ }^{-1}$ ) of mangabeira seedlings (Hancornia speciosa Gomes) grown in a complete nutrient solution or in macronutrient-deficient solutions. Rio Verde. IF Goiano. 2011.

\begin{tabular}{lcccccc}
\hline & \multicolumn{7}{c}{ Content $\left(\mathbf{m g}\right.$ plant $\left.^{-1}\right)$} \\
\hline TREATMENT & $\mathbf{N}$ & $\mathbf{P}$ & $\mathbf{K}$ & $\mathbf{M g}$ & $\mathbf{C a}$ & $\mathbf{S}$ \\
\hline Complete & $10.0^{1} \mathrm{a}^{2}$ & $2.10 \mathrm{a}$ & $7.0 \mathrm{a}$ & $1.0 \mathrm{a}$ & $4.0 \mathrm{ab}$ & $1.3 \mathrm{a}$ \\
$\mathbf{- ~ N}$ & $7.00 \mathrm{ab}$ & $0.70 \mathrm{ab}$ & $4.0 \mathrm{ab}$ & $1.0 \mathrm{a}$ & $10.0 \mathrm{ab}$ & $1.1 \mathrm{ab}$ \\
$\mathbf{- ~}$ & $3.00 \mathrm{ab}$ & $0.10 \mathrm{~b}$ & $4.0 \mathrm{ab}$ & $0.5 \mathrm{a}$ & $2.2 \mathrm{~b}$ & $0.4 \mathrm{bc}$ \\
$\mathbf{- ~ K}$ & $9.00 \mathrm{ab}$ & $0.90 \mathrm{ab}$ & $4.0 \mathrm{ab}$ & $1.0 \mathrm{a}$ & $12.0 \mathrm{a}$ & $1.0 \mathrm{abc}$ \\
$\mathbf{- ~ M g}$ & $1.80 \mathrm{~b}$ & $0.03 \mathrm{~b}$ & $1.0 \mathrm{~b}$ & $4.0 \mathrm{a}$ & $3.0 \mathrm{ab}$ & $0.2 \mathrm{c}$ \\
$\mathbf{- ~ C a}$ & $9.00 \mathrm{ab}$ & $1.00 \mathrm{ab}$ & $5.0 \mathrm{ab}$ & $1.0 \mathrm{a}$ & $5.0 \mathrm{ab}$ & $1.0 \mathrm{abc}$ \\
$\mathbf{- S}$ & $9.00 \mathrm{ab}$ & $2.00 \mathrm{a}$ & $5.0 \mathrm{ab}$ & $1.0 \mathrm{a}$ & $11.0 \mathrm{a}$ & $0.6 \mathrm{abc}$ \\
\hline $\mathbf{C V}(\mathbf{\%})^{3}$ & 0.19 & 0.04 & 0.11 & 0.03 & 0.20 & 0.02 \\
\hline
\end{tabular}

${ }^{1}$ Means shown with the original values. ${ }^{2}$ Means followed by the same letter in the column do not statistically differ according to Tukey's test $(\mathrm{p}<0.05)$. ${ }^{3}$ Coefficients of variation obtained after the data were transformed with an $\mathrm{x}+1$ base. 


\section{CONCLUSIONS}

1- The omission of $\mathrm{N}, \mathrm{P}, \mathrm{K}, \mathrm{Ca}, \mathrm{Mg}$, and $\mathrm{S}$ from the nutrient solution resulted in morphological especially changes in the stem length and number of leaves in the mangabeira plants, which produced the characteristic symptoms of each nutritional deficiency.

2- The lack of macronutrients resulted in a decrease in growth and in the production of dry matter in mangabeira compared with plants grown in the complete nutrient solution.

3- The RG values showed that the omission of macronutrients compromised the growth of the mangabeira plants.

4- The accumulation of macronutrients in the leaves of mangabeira plants displayed the order $\mathrm{N}>\mathrm{K}>\mathrm{Ca}>\mathrm{P}>\mathrm{S}>\mathrm{Mg}$.

\section{ACKNOWLEDGMENTS}

The authors would like to thank CAPES for the postdoctoral grant and FAPEG for financial support, as well as Mr. Arlindo Thomáz da Silva and family for donating the plant material used in this study.

\section{REFERENCES}

ALVES, A. U; PRADO, R. M. de; GONDIN, A, R, O, FONSECA, I. M; FILHO, A.B.C. Desenvolvimento e estado nutricional da beterraba em função da omisão de nutrientes. Horticultura Brasileira, Brasília, v.26, n.2, p.292-295, 2008.

AUGOSTINHO, L. M. D; PRADO, R. de M., ROZANE, D. E., FREITAS, N. Marcha de absorção de macro e micronutrientes em mudas de goiabeira 'Pedro Sato'. Bragantia, Campinas, v.67, n.3, p.563568, 2008.

BARROSO, D. G; FIGUEIREDO, F.A.M.A.; PEREIRA, R.C.; MENDOKA, A.V.R.; SILVA, L.C. Diagnóstico de deficiências de macronutrientes em mudas de teca. Revista Árvore, Viçosa, MG, v.29, n.5, p.671-679, 2005.

BATISTA, M. M. F; VIÉGAS, I. de J.M.; FRAZÃO, D.A.C.; TOMAZ, M.A.A.; SILVA, R. de C. L. da. Efeito da omissão de macronutrientes no crescimento, nos sintomas de deficiências nutricionais e na composição mineral em gravioleiras (Annona muricata). Revista Brasileira de Fruticultura, Jaboticabal, v.25, n.2, p.315-318, 2003.
FREITAS, M. S. M; MONNERAT, P.H; PINHO, L.G.R; CARVALHO, A. J. C Deficiência de macronutrientes e boro em maracujazeiro doce: qualidade dos frutos. Revista Brasileira de Fruticultura, Jaboticabal, v.28, n.3, p.492-496, 2006.

GONÇALVES, F. C; NEVES, O. S. C; CARVALHO, J. G. de. Deficiência nutricional em mudas de umbuzeiro decorrente da omissão de macronutrientes. Pesquisa Agropecuária Brasileira, Brasília, v.41, n.6, p.1053-1057, 2006.

HERMANS, C; VERBRUGGEN, N; Physiological characterization of $\mathrm{Mg}$ deficiency in Arabidopsis thaliana. Journal of Experimental Botany, Oxford, v.56, n.418, p.2153-2161, 2005.

HOAGLAND, D; ARNON, D.I. The water culture method for growing plants without soil. Berkeley: California Agriculture Experimental Station, 1950. $347 \mathrm{p}$.

KÖPPEN, W; GEIGER, R. Klimate der Erde. Gotha: Verlag Justus Perthes. 1928. Wall-map $150 \mathrm{~cm} \times 200 \mathrm{~cm}$.

LEDERMAN, I.E., SILVA JÚNIOR, J.F., BEZERRA, J.E.F., ESPINDOLA, A.C.M. Mangaba (Hancornia speciosa Gomes). Jaboticabal: FUNEP, 2000. 35 p.

MAlavolta, E. A. Avaliação do estado nutricional das plantas princípios e aplicações. 2. ed. Piracicaba: Associação Brasileira para Pesquisa da Potássio e do Fosfato, 1997. 319 p.

MALAVOLTA, E. A. Manual de nutrição mineral de plantas. São Paulo: Ceres, 2006. 638 p.

MALÉZIEUX, E; BARTHOLOMEW, D. P. Plant Nutrition. In: BARTHOLOMEW, D.P.;PAUL, R.E., ROHRBACH, K.G. (Ed.). The pineapple: botany, production and uses. Honolulu: CABI Publishing, 2003. p-143-165.

MARENCO, R. A.; LOPES, N. F. Fisiologia vegetal: fotossíntese, respiração, relações hídricas e nutrição mineral. Viçosa: UFV, 2005. 451 p.

MARSCHNER, H. Mineral nutrition of higher plants. New York: Academic Press, 1995. 889 p. 
RAMOS, M. J.; MONNERAT, P. H.; CARVALHO, A. J. C.; PINTO, J. L. A.; SILVA, J. A. Sintomas visuais de deficiência de macronutrientes e de Boro em Abacaxizeiro Imperial. Revista Brasileira de Fruticultura, Jaboticabal, v.31, n.1, p.252-256, 2009.

ROSA, M. E. C. da; NAVES, R. V.; OLIVEIRA JÚNIOR, J. P. de. Produção e crescimento de mudas e mangabeira (Hancornia speciosa Gomes) em diferentes substratos. Pesquisa Agropecuária Tropical, Goiânia, v.35, n.2, p.65-70, 2005.

SILVA, JUNIOR. M. L. da; SEABRA, D. A.; MELO, V. S. de; SANTOS, M. M. L. S.; SANTOS, P. C. T. C. dos. Crescimento, composicão mineral e sintomas de deficiências de pariri cultivado sob omissão de macronutrientes. Ciências Agrárias, Belém, n.48, p.85-97, 2007.

SILVA, J. T. A. da; CARVALHO, J. G. de. Avaliação nutricional de bananeira prata-anã (aab), sob irrigação no semiárido do norte de Minas Gerais, pelo método DRIS. Ciência e Agrotecnologia, Lavras, v.29, n.4, p.731-739, 2005.

TAIZ, L.; ZEIGER, E. Fisiologia vegetal. 3. ed. Porto Alegre: Artmed, 2004. 722 p.
VIÉGAS, I. J. de; GONÇALVES, A. A. S. da; FRAÇÃO, D. A. C; CONCEIÇÃO, H. E. O. da. Efeitos das omissões de macronutrientes e boro na sintomatologia e crescimento em plantas de açaizeiro (Euterpe oleracea Mart.). Ciências Agrárias, Belém, n.50, p.129-141, 2008.

VIEGAS, I. J. M.; THOMAZ, M. A. A.; SILVA, J. F.; CONCEIÇÃO, E. O.; NAIFF, A. P. M. Efeitos da omissão de macronutrientes e Boro no crescimento, nos sintomas de deficiência nutricionais e na composição mineral de plantas de camucamuzeiro. Revista Brasileira de Fruticultura, Jaboticabal, v.26, n.2, p.315-319, 2004.

VIEIRA, H.; CHAVES, L. H. G; VIÉGAS, R. H. Crescimento inicial de moringa (Moringa oleifera lam) sob omissão de nutrientes. Revista Caatinga, Mossoró, v.21, n.4, p.51-56, 2008.

WHITE, P.J; BROADLEY, M.R. Biofortification of crops with seven mineral elements often lacking in human diets: iron, zinc, copper, calcium, magnesium, selenium and iodine. New Phytologist, London, v.182, n.1, p.49-84, 2009. 